\title{
PENERAPAN MODEL PEMBELAJARAN TALKING STICK TERHADAP KEMAMPUAN PEMECAHAN MASALAH MATEMATIKA SISWA KELAS VII
}

\author{
Helma Mustika ${ }^{1}$, Halim Musliman ${ }^{2}$ \\ Program Studi Pendidikan Matematika, STKIP Insan Madani Airmolek \\ helmamustika@ymail.com, halimmusliman17@gmail.com
}

\begin{abstract}
This study aims to determine the differences in mathematical problem solving abilities between students in the class who get Talking Stick learning and students in the class who get conventional learning. The population of this study was the seventh grade students of Pasir Penyu 3 Public Middle School. Of the six classes, 168 students were enrolled in six classes. The type of research is Quasi Experimental Design, with the Randomized Subjects posttes only control group design. The data analysis technique used is Cluster Random Sampling. The data analysis technique used for the test problem solving ability was students namely the t-test.

Based on the results of hypothesis testing research indicated by $t \_c o u n t=$ $2.118>$ t_table $=2.005$ with a significant level of 0.05. This means that $\mathrm{HO}$ is rejected, thus the ability to solve students 'mathematical problems with the implementation of the Talking Stick model is better than the results of tests of students' mathematical problem solving abilities using conventional learning in class VII of Pasir Penyu 3 Public Middle School.
\end{abstract}

Keywords: : Problem Solving, Talking Stick

\begin{abstract}
ABSTRAK
Penelitian ini bertujuan untuk mengetahui perbedaan kemampuan pemecahan masalah matematika antara siswa pada kelas yang memperoleh pembelajaran Talking Stick dengan siswa pada kelas yang memperoleh pembelajaran konvensional. Populasi penelitian ini adalah siswa kelas VII SMP Negeri 3 Pasir Penyu. Dari enam kelas, di peroleh 168 siswa yang tebagi di enam kelas. Jenis penelitian adalah Quasi Experimental Design, dengan rancangan penelitian Randomized Subjects posttes only control group design. Teknik analisis data yang digunakan adalah Cluster Random Sampling. Teknik analisis data yang digunakan terhadap soal tes kemampuan pemecahan masalahsiswa yaitu uji-t.

Berdasarkan hasil penelitian pengujian hipotesis ditunjukkan oleh $t_{\text {hitung }}=$ $2,118>t_{\text {tabel }}=2,005$ dengan taraf signifikan 0,05. Artinya $H_{0}$ di tolak, dengan demikian kemampuan pemecahan masalah matematika siswa dengan penerapan model Talking Stick lebih baik daripada hasil test kemampuan pemecahan masalah matematika siswa denan menggunakan pembelajaran konvensional pada kelas VII SMP Negeri 3 Pasir Penyu.
\end{abstract}

Kata Kunci: Kemampuan Pemecahan Masalah, Talking Stick 


\section{PENDAHULUAN}

Mata pelajaran matematika merupakan salah satu mata pelajaran yang di pelajari disekolah. Pelajaran matematika merupakan jantung dari mata pelajaran lain. Maksudnya semua mata pelajaran yang ada, didalamnya melibatkan matematika. Matematika bersifat abstrak sehingga sulit untuk dipahami. Untuk itu guru harus mempunyai kemampuan untuk membuat suasana pembelajaran yang menyenangkan dengan menggunakan model pembelajaran yang tepat.

Kemampuan matematika yang harus dimiliki siswa adalah kemampuan pemecahan masalah. Pentingnya belajar pemecahan masalah dalam matematika, banyak ahli yang mengatakannya. Salah satunya menurut Bell (1978) hasil-hasil penelitian menunjukkan bahwa strategi-strategi pemecahan masalah yang umumnya dipelajari dalam pelajaran matematika, dalam hal-hal tertentu, dapat ditransfer dan diaplikasikan dalam situasi pemecahan masalah yang lain. Penyelesaian masalah secara matematis dapat membantu para siswa meningkatkan daya analitis mereka dan dapat menolong mereka dalam menerapkan daya tersebut pada bermacam-macam situasi. ${ }^{1}$ Pembelajaran matematika perlu diajarkan sejak dini agar generasi penerus dapat berkompetensi dalam persaingan global. Untuk itu, guru sangat berperan penting dalam pembelajaran matematika. Dalam hal ini yang menjadi permasalahan adalah kurangnya kemampuan pemecahan masalah dalam pembelajaran matematika. Dapat dilihat dari observasi yang telah dilakukan peneliti.

Berdasarkan observasi pada tangal 24 februari - 26 februari 2016 dengan mengikuti pembelajaran yang dilakukan oleh guru bidang studi SMP Negeri 3 Pasir Penyu, dalam proses belajar mengajar yang dilakukan hanya menggunakan metode ceramah, diskusi dan tanya jawab. Jadi, proses pembelajaran kurang optimal. Selain itu, Salah satu faktor penyebab rendahnya kemampuan pemecahan masalah matematika siswa adalah kurangnya minat dan motivasi siswa dalam belajar matematika, dan kurangnya kemampuan dalam memecahkan masalah terhadap persoalan yang diberikan oleh guru. Hal ini dapat dilihat dari kemampuan pemecahan masalah matematika siswa masih banyak yang nilainy di bawah KKM yaitu 70, hasil itu dapat dilihat dari hasil ulangan siswa pada Tabel I berikut.

Tabel 1. Hasil Nilai Ulangan Harian Siswa Kelas VII

\begin{tabular}{|c|c|c|c|c|}
\hline \multirow{2}{*}{ KELAS } & \multicolumn{2}{|c|}{ UH 1 } & \multicolumn{2}{c|}{ UH 2 } \\
\cline { 2 - 5 } & TUNTAS & $\begin{array}{c}\text { TIDAK } \\
\text { TUNTAS }\end{array}$ & TUNTAS & $\begin{array}{c}\text { TIDAK } \\
\text { TUNTAS }\end{array}$ \\
\hline VII $^{1}$ & 14 & 13 & 11 & 16 \\
\hline VII $^{2}$ & 10 & 19 & 10 & 19 \\
\hline VII $^{3}$ & 10 & 18 & 7 & 21 \\
\hline VII $^{4}$ & 13 & 15 & 12 & 16 \\
\hline VII $^{5}$ & 11 & 17 & 3 & 25 \\
\hline VII $^{6}$ & 18 & 10 & 21 & 7 \\
\hline JUMLAH & 76 & 92 & 64 & 104 \\
\hline
\end{tabular}

Berdasarkan tabel di atas, pada ulangan harian hanya beberapa siswa yang tuntas, dikarenakan kurangnya kemampuan pemecahan masalah pada siswa. Ini terjadi akibat penggunaan strategi atau model pembelajaran yang diambil oleh guru kurang 
tepat, sehingga anak kurang memahami dalam belajar matematika. Salah satu cara untuk mengatasi masalah tersebut diperlukan model pembelajaran yang dapat meningkatkan kemampuan pemecahan masalah siswa. Salah satu model pembelajarannya yaitu model pembelajaran talking stick. Model pembelajaran talking stick mendorong peserta didik untuk berani mengemukakan pendapat. Selain itu, model pembelajaran ini membuat siswa menjadi aktif, semangat dalam proses belajar dan bergembira dalam proses belajar, karena model ini diiringi dengan musik yang membuat mereka terhibur dan juga tidak takut lagi dalam belajar matematika..

Pembelajaran dengan model talking stick mendorong peserta didik untuk berani mengemukakan pendapat. Model pembelajaran talking stick diawali oleh penjelasan guru mengenai materi pokok yang akan dipelajari. Peserta didik diberi kesempatan membaca dan mempelajari materi tersebut., berikan waktu yang cukup untuk aktifitas ini. Guru selanjutnya meminta kepada peserta didik menutup bukunya. Guru mengambil tongkat yang telah disiapkan sebelumnya. Tongkat tersebut diberikan kepada salah satu peserta didik. Peserta didik yang menerima tongkat tersebut demikian seterusnya. Ketika stick bergulir dari peserta didik lainnya. Seyogyanya diiringi musik. Langkah akhir dari model talking stick adalah guru memberikan kesempatan kepada peserta didik melakukan refleksi terhadap materi yang dipelajarinya. Guru memberi ulasan terhadap seluruh jawaban yang diberikan peserta didik, selanjutnya sama-sama peserta didik merumuskan kesimpulan.

Berdasarkan identifikasi dan batasan masalah yang telah diuraikan di atas, selanjutnya perumusan masalah dalam penelitian ini adalah: "Apakah Kemampuan Pemecahan Masalah Matematika Siswa dengan Penerapan Model Pembelajaran Talking Stick Lebih Baik daripada Kemampuan Pemecahan Masalah Matematika Siswa dengan Pembelajan Konvensional di Kelas VII SMP Negeri 3 Pasir Penyu"

Dari rumusan masalah di atas maka penelitian ini bertujuan untuk: mengetahui Kemampuan Pemecahan Masalah Matematika Siswa dengan Menggunakan Model Pembelajaran Talking Stick Lebih Baik daripada Kemampuan Pemecahan Masalah Matematika Siswa dengan Pembelajaran Konvensional di Kelas VII SMP Negeri 3 Pasir Penyu.

Manfaat dari penelitian ini adalah :

1. Bagi Guru

Penerapan model pembelajaran Talking Stick dapat dijadikan salah satu model pembelajaran yang baik diterapkan dalam meningkatkan pembelajaran matematika yang efektif.

2. Bagi Siswa

Diharapkan hasil belajar siswa kelas VII Sekolah Menengah Pertama Negeri 3 Pasir Penyu dalam pelajaran matematika dapat meningkatkan melalui penerapan model pembelajaran talking stick terutama pada materi Segitiga. Dan siswa diharapkan lebih tertarik dalam pembelajaran. Selain itu dapat melatih siswa untuk lebih aktif dalam proses belajar mengajar dan dapat memotivasi siswa untuk belajar matematika.

\section{Bagi Peneliti}

Sebagai salah satu syarat dalam menyelesaikan perkuliahan pada Sekolah Tinggi Keguruan dan Ilmu Pendidikan Insan Madani Airmolek, dan juga dalam hal menambah kwalitas dan wawasan ilmu pengetahuan peneliti.

\section{Bagi sekolah}

Diharapkan penerapan model pembelajaran Talking Stick dapat dijadikan salah satu bahan masukan dalam rangka meningkatkan kuwalitas pembelajaran matematika di 
Sekolah Menengah Pertama Negeri 3 Pasir Penyu. Dan hasil penelitian ini dapat memberikan sumbangan yang baik bagi sekolah dalam rangka memperbaiki dan meningkatkan mutu sekolah.

\section{METODOLOGI PENELITIAN}

Penelitian ini dilaksanakan dengan menggunakan metode eksperimen semu dengan pendekatan kuantitatif. Terdapat dua kelompok sampel pada penelitian ini yaitu kelompok eksperimen yang dilaksanakan dengan model Talking Stick dan kelompok kontrol dengan pembelajaran konvensional.

Rancangan penelitian yang digunakan adalah Randomized Subjects Posttest Only Control Group Design. Untuk lebih jelasnya disain penelitian digambarkan pada Tabel berikut:

Tabel 2. Randomized Subjects Posttest Only Control Group Design

\begin{tabular}{|c|c|c|c|}
\hline & Grup & Variabel Terikat & Postes \\
\hline$(\mathrm{R})$ & Eksperimen & $\mathrm{X}$ & $\mathrm{Y}_{1}$ \\
$(\mathrm{R})$ & Kontrol & - & $\mathrm{Y}_{2}$ \\
\hline
\end{tabular}

Keterangan :

$\mathrm{X}$ : Perlakuan yang diberikan

$\mathrm{Y}_{1}$ : Tes kelompok eksperimen

$\mathrm{Y}_{2}$ : Tes kelompok kontrol

Populasi dalam penelitian ini adalah siswa kelas VII SMP Negeri 3 Pasir Penyu yang berjumlah 140 orang. Dalam penelitian ini dibutuhkan dua kelas sampel yaitu kelas eksperimen dan kelas kontrol. Pengambilan sampel dilakukan secara random dengan jenis cluster random sampling. Pengambilan sampel secara cluster (rumpun) merupakan pengambilan sampel pada kelompok individu-individu yang telah ada disekolah yaitu kelas, bukan siswa secara individual. Cara ini dilakukan jika populasi dianggap homogen.

Adapun langkah-langkah pengambilan sampel dalam penelitian ini adalah sebagai berikut:

a. Mengumpulkan nilai ulangan harian matematika kelas VII Sekolah Menengah Pertama Negeri 3 Pasir Penyu.

b. Melakukan Uji normalitas menggunakan uji liliefors dan diolah menggunakan aplikasi SPSS. Dari hasil pengujian di poeroleh hasil yang di sajikan kedalam Tabel 3 berikut;

Tabel 3. hasil Uji Normalitas Populasi

\begin{tabular}{|c|c|c|}
\hline Kelas & Hasil Pengujian & Keterangan \\
\hline VII 1 & 0,209 & Normal \\
\hline VII 2 & 0,081 & Normal \\
\hline VII 3 & 0,200 & Normal \\
\hline VII 4 & 0,090 & Normal \\
\hline
\end{tabular}




\begin{tabular}{|c|c|c|}
\hline VII 5 & 0,130 & Normal \\
\hline VII 6 & 0,200 & Normal \\
\hline
\end{tabular}

Dari tabel 3 terdapat nilai sig > 0,05, yang berarti bahwa populasi berdistribusi normal.

c. Melakukan uji Homogenitas

Dari penggunaan Homogenitas di dapatkan nilai sig 0,219>0,05 yang berarti bahwa populasi mempunyai varians yang homogeny.

d. Melakukan uji kesamaan rata-rata

Dari pengujian kesamaan rata-rata diperoleh nilai sig $0,115>0,05$ yang berarti bahwa populasi mempunyai tara-rata yang sama.

e. Setelah uji dilakukan langkah terakhir yaitu membuat kertas anggota populasi dan digulung. Kemudian diambil secara acak sampel yang dibutuhkan. Dari hasil pengambilan kertas didapatkan kelas $\mathrm{VII}^{3}$ sebagai kelas kontrol dan kelas $\mathrm{VII}^{5}$ sebagai kelas eksperimen.

Pada penelitian ini ada tiga variabel yaitu :

a. Variabel bebas yaitu model pembelajaran

b. Variabel terikat yaitu kemampuan pemecahan masalah matematis.

Untuk keragaman pandangan antara peneliti dengan pembaca, maka perlu dijelaskan beberapa istilah penting yang digunakan dalam penelitian ini:

1) Model Pembelajaran Talking Stick

Model Pembelajaran menurut Soekamto, dkk (dalam Nurulwati, 2000: 10) mengemukakan maksud dari model pembelajaran yaitu "kerangka konseptual yang melukiskan prosedur yang sistematis dalam mengorganisasikan pengalaman belajar untuk mencapai tujuan belajar tertentu, dan berfungsi sebagai pedoman bagi para perancang pembelajaran dan para pengajar dalam merencanakan aktivitas belajar mengajar.

Pembelajaran Talking stick mendorong peserta didik untuk berani mengemukakan pendapat. Pembelajaran dengan metode talking stick di awali oleh penjelasan guru mengenai materi pokok yang akan di pelajari.

2) Kemampuan pemecahan masalah. Pemecahan masalah merupakan kemampuan siswa dalam menyelesaikan masalah matematika dengan memperhatikan proses penemuan jawaban berdasarkan langkah-langkah pemecahan masalah yaitu :

a. Memahami masalah,

b. Merencanakan penyelesaian,

c. Melaksanakan rencana,

d. Memeriksa kembali kebenaran jawaban.

\section{HASIL DAN PEMBAHASAN}

Tes kemampuan pemecahan masalah diberikan untuk mengukur kemampuan siswa dalam memecahkan soal-soal pada materi luas dan volume prisma dan limas setelah dilakukan pembelajaran dengan model probing prompting pada kelompok eksperimen dan konvensional pada kelompok kontrol.

Setelah diberikan perlakuan yang berbeda, kemudian kedua kelas diberi posttest untuk mengukur kemampuan pemecahan masalah. Hasil posttest ini dijadikan data untuk menguji hipotesis dalam penelitian. Sebelum hipotesis dilakuan terlebih dahulu dilakukan uji normalitas dan homogenitas. 
a. Uji Normalitas

Pengujian normalitas ini dengan menggunakan uji Liliefors. Uji normalitas bertujuan untuk mengetahui apakah data berasal dari sampel berdistribusi normal atau tidak. Uji normalitas pada kelas sampel dengan $\alpha=0,05$ dapat dilihat pada Tabel 4.

Tabel 4. Hasil Uji Normalitas Data

\begin{tabular}{|c|c|c|c|c|}
\hline $\begin{array}{c}\text { Jumlah Sampel } \\
(\mathbf{N})\end{array}$ & $\begin{array}{c}\text { Rata-rata } \\
(\overline{\boldsymbol{X}})\end{array}$ & $\begin{array}{c}\text { Simpangan Baku } \\
(\mathbf{S})\end{array}$ & Lo & L \\
\hline 56 & 80,143 & 9,737 & 0,090 & 0,119 \\
\hline
\end{tabular}

Dari tabel 4.3 di atas diperoleh $\mathrm{L}_{0}=0,090$ dengan $n=56$ dan taraf nyata $\alpha=$ 0,05 dari daftar nilai kritis $\mathrm{L}=0,090$. Kriteria pengujian adalah $\mathrm{H}_{0}$ diterima jika nilai $\mathrm{L}_{0}$ kurang dari nilai kritis L. Dari hasil perhitungan diperoleh bahwa $\mathrm{L}_{0}<\mathrm{L}$, jadi $\mathrm{H}_{0}$ diterima. Dengan demikian, data berasal dari populasi yang berdistribusi normal.

b. Uji Homogenitas

Selain data berasal dari sampel berdistribusi normal, harus diperhatikan juga apakah kedua sampel homogen atau tidak. Maka dilakukan uji homogenitas dengan $\alpha=0,05$ dengan $\mathrm{dk}=55$. Hasil uji homogenitas dapat dilihat pada Tabel 5 .

Tabel 5. Hasil Analisis Homogenita Kelas Sampel

\begin{tabular}{|c|c|c|c|c|c|}
\hline Kelas & $\mathbf{n}$ & Varians & F $_{\text {hitung }}$ & F $_{\text {tabel }}$ & Kesimpulan \\
\hline Eksperimen & 28 & 96,100 & \multirow{2}{*}{1.382} & \multirow{2}{*}{1.905} & \multirow{2}{*}{ Homogen } \\
\hline Kontrol & 28 & 69,518 & & & \\
\hline
\end{tabular}

Dari tabel 5 dengan uji Hartley, diperoleh varians untuk kelompok eksperimen adalah 96,100 dan varians untuk kelompok kontrol adalah 69,518. Setelah dilakukan pengujian homogenitas, diperoleh $\mathrm{F}_{\text {hitung }}=1.382$ dengan $\mathrm{dk}=28$ dan taraf nyata $\alpha=0,05$ dari distribusi $\mathrm{F}$ diperoleh $\mathrm{F}_{\text {tabel }}=\mathrm{F}_{(0.025)(32,32)}=1.905$. Kriteria pengujian $\mathrm{H}_{0}$ diterima jika nilai $\mathrm{F}_{\text {hitung }}$ kurang dari $\mathrm{F}_{\text {tabel. }}$

Dari hasil perhitungan diperoleh bahwa $\mathrm{F}_{\text {hitung }}<\mathrm{F}_{\text {tabel. }}$. Jadi $\mathrm{H}_{0}$ diterima. Dengan demikian, kedua kelompok memiliki varians yang sama atau kedua kelas homogen.

c. Pengujian Hipotesis

Pengujian hipotesis digunakan untuk mengetahui hasil posttest kemampuan pemecahan masalah matematika siswa yang dikenai model probing prompting lebih baik daripada hasil posttest kemampuan pemecahan masalah matematika siswa dikenai model konvensional pada materi luas dan volume prisma dan limas di kelas VII SMP Negeri 3 Lirik. Hasil uji hipotesis dapat dilihat pada Tabel berikut.

Tabel 6. Hasil Uji Hipotesis

\begin{tabular}{|c|c|c|c|c|c|c|}
\hline Kelas & $\mathbf{N}$ & $\begin{array}{c}\text { Rata-rata } \\
(\overline{\boldsymbol{X}})\end{array}$ & $\begin{array}{c}\text { Simpangan } \\
\text { Baku (S) }\end{array}$ & $\begin{array}{c}\text { Varians } \\
\left(\mathbf{S}^{2}\right)\end{array}$ & thitung & t tabel \\
\hline Eksperimen & 28 & 83.786 & 9.803 & 96,100 & \multirow{2}{*}{2.118} & \multirow{2}{*}{2.005} \\
\cline { 1 - 5 } Kontrol & 28 & 76.500 & 8.338 & 69,518 & & \\
\hline
\end{tabular}

Dari tabel di atas diperoleh hasil perhitungan uji hipotesis diperoleh $t_{\text {hitung }}=$ 2,118 dengan $\mathrm{dk}=(28+28-1)=55$ dan taraf nyata $5 \%$ maka diperoleh $\mathrm{t}_{\text {tabel }}=$ 2.005. Karena $t_{\text {hitung }}$ berada pada daerah penolakan $\mathrm{H}_{0}$, artinya hasil posttest 
kemampuan pemecahan masalah matematika siswa yang dikenai model talking stick lebih baik dari pada hasil posttest kemampuan pemecahan masalah matematika siswa yang dikenai pembelajaran konvensional pada materi segitiga di kelas VII SMP Negeri 3 Pasir Penyu.

\section{PEMBAHASAN HASIL PENELITIAN}

Pelaksanaan pembelajaran atau penelitian mulai dilakukan pada hari Rabu, tanggal 06 April 2016. Hari pertama penelitian dimulai dengan masuk ke kelas kontrol jam pertama dan kedua, kemudian kelas eksperimen masuk jam ketiga dan keempat. Pelaksanaan pembelajaran pada kedua kelas penelitian diawali dengan apersepsi yang berkaitan dengan segitiga. Seperti menunjukan bentuk-bentuk segitiga yang terdapat pada lingkungan sekitar dan menjelaskan tentang sudut dan sisi segitiga pada kelas kontrol pembelajaran dilakukan dengan memberikan materi seperti biasa dengan menggunakan model pembelajaran konvensional, menjelaskan materi kemudian memberikan kuis kepada siswa dan tugas rumah. Sedangkan pada kelas eksperimen menerapkan model pembelajaran yang digunakan yaitu model pembelajaran talking stick, siswa diberikan soal latihan, kemudian siswa mengerjakan dengan diskusi kecil yang terdiri dari 3 sampai 4 orang siswa. Setelah itu guru memberikan pertanyaan kepada siswa yang berkaitan dengan soal latihan. Setelah pembahasan materi dari soal latihan siswa diberi kuis dan akhir pelajaran siswa diberi tugas rumah.

Hari kedua pada tanggal 8 April 2016, peneliti kembali masuk ke kelas kontrol dan kelas eksperimen. Seperti biasanya kelas kontrol dengan menerapkan model pembelajaran konvensional. Memberi tugas kepada siswa. Selanjutnya masuk kekelas eksperimen, di kelas eksperimen siswa selalu bersemangat dan aktif menjawab pertanyaan dari guru, dan memberikan pendapat.

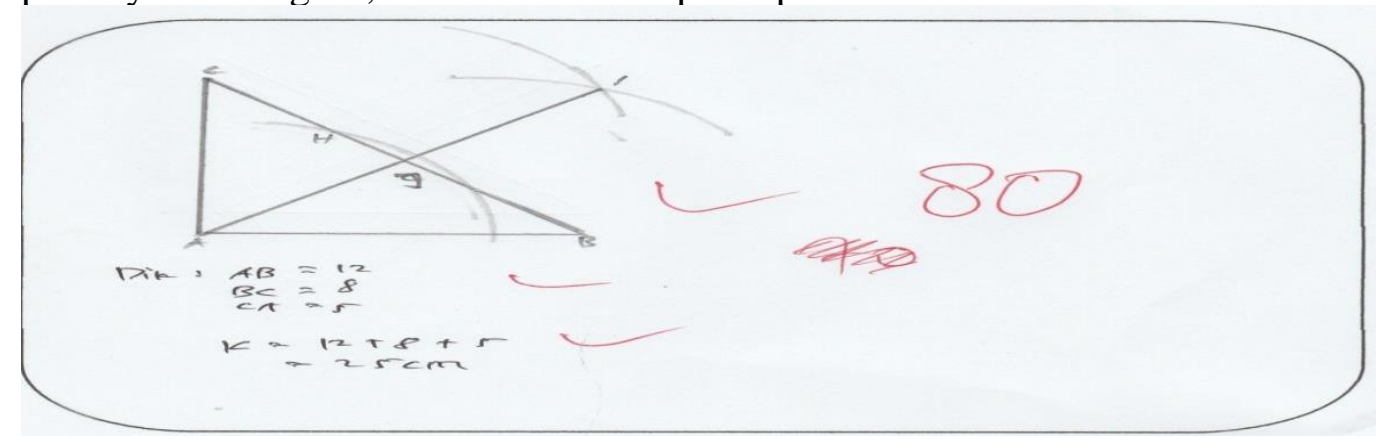

\section{Gambar 1. jawaban kuis}

Pada pertemuan ketiga hari Selasa tanggal 13 April 2016, proses pembelajaran sudah bisa dikatakkann baik dari kelas eksperimen dari pada kelas kontrol. Begitu juga pada pertemuan keempat hari Jumat tanggal 15 April 2016. Hal ini dapat dilihat dari soal latihan pemecahan masalah yang diberikan di kelas eksperimen sudah bisa mencapai semua indikator sedangkan kelas kontrol belum mencapai semua indikator pemecahan masalah, seperti gambar di bawah ini.

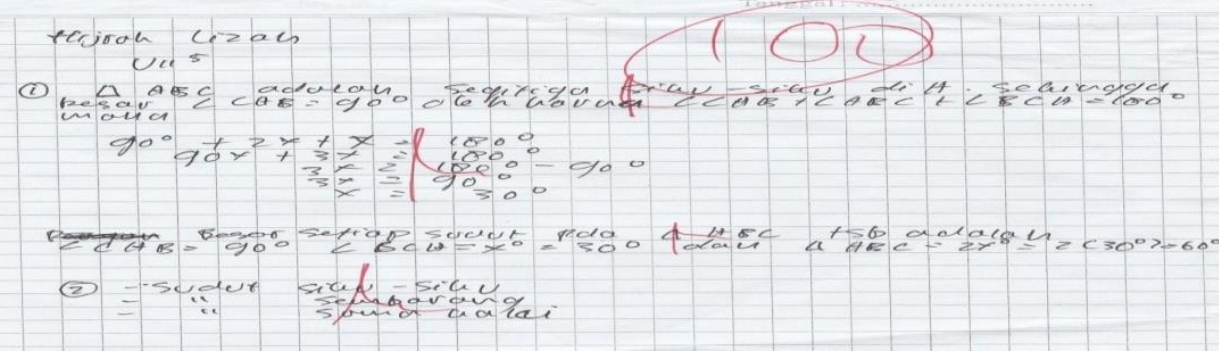




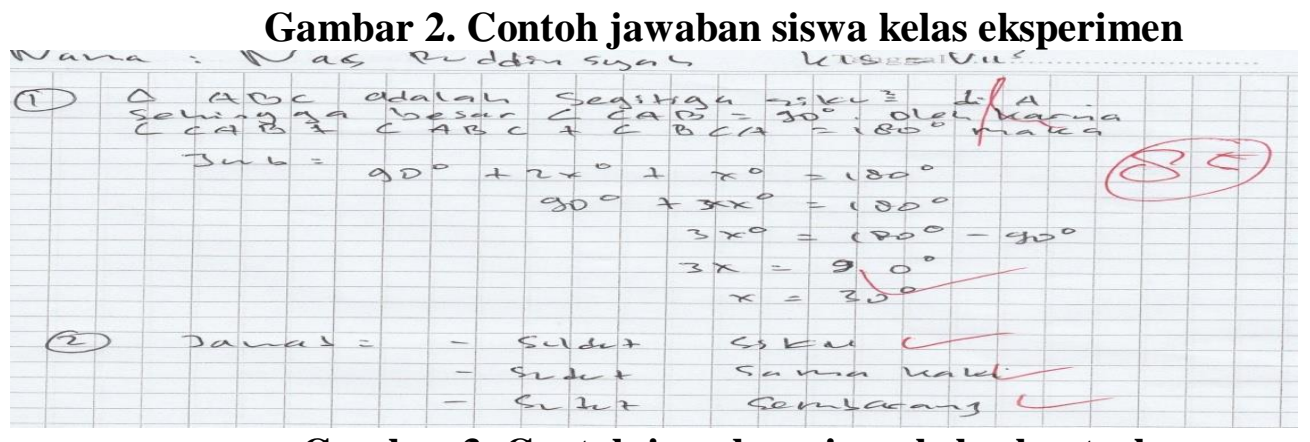

Gambar 3. Contoh jawaban siswa kelas kontrol

Dari gambar di atas dapat disimpulkan bahwa kemampuan pemecahan masalah dengan menerapkan model pembelajaran Talking Stick lebih baik dari pada kemampuan pemecahan masalah dengan pembelajaran konvensional. Penelitian ini merupakan penelitian eksperimen yang menggunakan dua kelas, yaitu siswa pada kelas VII $^{3}$ sebagai kelas kontrol dan siswa pada kelas VII ${ }^{5}$ sebagai kelas eksperimen.

Hari ketiga dan keempat pada tanggal 13 dan 15 April 2016 penelitian di kelas eksperimen dapat dilihat perkembangan keaktifan siswa model pembelajaran yang diterapkan, siswa muali terbiasa dengan pertanyaan yang diberikan guru, tidak merasa malu saat memberi jawaban. Siswa tidak perlu ditunjuk untuk menjawab pertanyaan yang diberikan guru tetapi mereka sudah siap menjawab pertanyaan yang diberikan, kemudian siswa diberi kuis dan pekerjaan rumah seperti pembelajaran sebelumnya.

\section{SIMPULAN DAN SARAN}

Berdasarkan hasil penelitian dan pembahasan diperoleh simpulan tentang penerapan model pembelajaran talking stick terhadap kemampuan pemecahan masalah matematika siswa kelas VII SMP Negeri 3 Pasir Penyu dalam menyelesaikan segitiga.

1) Kemampuan pemecahan masalah matematika siswa dalam menyelesaikan soal pada materi segitiga dikelas yang menggunakan model pembelajaran talking stick mencapai ketuntasan belajar.

2) Kemampuan pemecahan masalah matematika siswa menggunakan model pembelajaran talking stick lebih baik daripada siswa kelas yang menggunakan pembelajaran kovensional dalam menyelesaikan soal materi segitiga kelas VII SMP Negeri 3 Pasir Penyu.

Berdasarkan kesimpulan dan implikasi yang telah diuraikan sebelumnya, peneliti mengemukakan beberapa saran sebagai berikut:

Saran yang dikemukakan pada penelitian ini adalaah dengan tujuan membangun. Saran tersebut dapat diuraikan sebagai berikut.

1) Pada saat menerapkan model talking stick, guru perlu memperhatikan alokasi waktu dan peran aktif peserta didik.

2) Guru dapat menjadikan model talking stick sebagai salah satu alternative strategi belajar untuk mengajarkan materi segitiga. Karena dengan model tersebut, siswa memiliki kemampuan pemecahan masalah yang lebih baik di banding dengan pembelajaran yang biasa digunakan, yaitu konvensional.

3) Penelitian ini hanya mengkaji faktor model pembelajaran terhadap kemampuan pemecahan masalah siswa pada materi tertentu. Diharapkan adanya penelitian lebih lanjut. Yang mengkaji faktor-faktor lain sebagai pengembangan penelitian ini. 


\section{DAFTAR PUSTAKA}

Arikunto, Suharsimin. 2013. Prosedur Penelitian. Jakarta : PT Rineka Cipta 2013. Dasar-dasar Evaluasi Pendidikan. Jakarta: Bumi Aksara

Bondan Idjajanti, Djamilah. 2009. Kemampuan Pemecahan Masalah Matematis Mahasiswa Calon Guru Matematika. diakses dari http://eprints.uny.ac.id/7042

Darmadi, Hamid. 2013. Metode Penelitian Pendidikan dan Sosial. Bandung: ALFABETA

Husna, dkk. 2013. Peningkatan Kemampuan Pemecahan Masalah dan komunikasi Matematika siswa SMP Melalui Moel Pembelajaran Kooperatif Tipe TPS. diakses di internet.

Istarani. 2012. Model pembelajaran inovatif. Medan: Media Persada

Ras Eko. 2011. Model Pembelajaran Talking Stick, di akses dari http://www.raseko.com/2011/-5/model-pembelajaran-talking-stick.html?m=1

Setyosari, Punaji. 2013. Metodologi Penelitian Pendidikan dan Pengembangan. Jakarta: kencana prenadamedia group

Slameto. 2003. Belajar dan Faktor-Faktor yang Mempengaruhinya. Jakarta: Renika Cipta

Wardhani, Sri. 2008. Analisis S1 dan SKL Mata pelajaran Matematika SMP/MTs Untus Optimalisasi Pencapaian Tujuan.Yogyakarta: Pusat Pengembangan dan Pemberdayaan Pendidikan dan Tenaga Kependidkan Matematika.

Sundayana, Rostina. 2010. Statistika Penelitian Pendidikan. Garut: STKIP Garut Press

Tita Rosita, Neneng. 2013. Pendekatan Pembelajaranm Matematika Realistik untuk Meningkatkan Kemampuan Pemecahan Masalah Matematika Siswa SD. diakses di internet

Trianto. 2007. Model-model Pembelajaran Berorientasi Konstruktivisme. Jakarta: PT Bumi Aksara

Sudjana, Nana. 2002. Dasar-Dasar Proses Belajar Menagajar. Bandung: Sinar Baru Algensindo 